\title{
Fanø Nordsøbad \\ - mellem dansk og tysk 1890-1904
}

af forskningsbibliotekar, dr.phil. John T. Lauridsen

Fanø ud for Esbjerg ved Jyllands vestkyst har i de sidste 150 år været benyttet som badested. I de første halvt hundrede år var det kun de energiske og udholdende, der trods rejsens besværligheder og de primitive faciliteter på stedet, indlod sig på at nå frem til det beskedne "Hotel Fanø Vesterhavsbad"1. Som det blev skrevet i "Folkekalender for Danmark $1855^{\prime \prime}$, så var stedet ypperligt for den, der ville bruge søbade for sit helbreds skyld alene, men den der tillige ønskede adspredelse i musik, dans, spil eller sligt gjorde bedst i at holde sig derfra ${ }^{2}$. Så fulgte krigen med Tyskland og tabet af Sønderjylland. Det gav et nyt perspektiv på Fanøs muligheder. Distriktslægen i Nordby, J. H. Lorck, skrev året efter: "Danmark har som bekendt tabt den gruppe af øer, som ligger langs den slesvigske vestkyst, og det badested, som før blev en del besøgt herfra, nemlig Wyck på Føhr, er gået over i fjendtlige hænder ... Det er sandsynligt, at ingen dansk vil besøge disse bade, sålænge de er i tysk vold og under tysk herredømme. Det er derfor heldigt, at vi endnu besidder et nordsøbad på Fanø, der ganske er under de samme betingelser som Wyck, hvor derfor alle de samme fordele kunne opnås ved siden af omgangen med en loyal befolkning ... Vi tør vel anse det for glædeligt, dersom det kunne lykkes at hæve dette danske badested lige overfor dets mere eller mindre fortyskede konkurrenter."3 Opfordringen var uden resultat, og årsagen skal vel snarest søges $i$, at et større badeprojekt kun havde noget for sig, hvis man kalkulerede med de tyske kunder. Danmark kunne ved den tid ikke alene danne grundlaget for et storstilet foretagende.

Knapt 15 år senere vovede A. Falkmann sig til Fanø, ud til Danmarks Far-West, og fik udgivet en bog med samme titel, for det var i de tider, hvor den læsende danske offentlighed med lige så stor interesse ind- 
sugede nyheder om opdagelsesrejser i Afrika som i det fjerne Jylland. Efter at have konstateret, at Esbjerg var fortvivlet kedsommelig, et topmål af barhed og nøgenhed, slog tonen om ved mødet med Fanøs vesterhavsstrand. Falkman så mulighederne for at bringe civilisationen hertil: "Dersom der er noget sted i Norden, der ypperlig egner sig til anlæg af et stort badeetablissement af den art, som der findes i mængde langs Nordsøens kyster, så er det Fanø vesterhavsstrand." 4 . Der var to gode grunde dertil: Dels det friske saltholdige vand, dels strandens og havbundens beskaffenhed. Der fremkom vitterligt også kort efter, i 1881, et projekt med moderne hoteller og pavilloner, der skulle føre Fanø ind på det europæiske kulturlandkort. Der blev også indbudt til aktietegning for projektet - og derved blev $\operatorname{det}^{5}$. Investorerne meldte sig ikke, og Skagen var fra 1870'erne det foretrukne område for den lille gruppe af malere og skribenter, hovedsageligt fra hovedstaden, som kunne finde sig til rette under de primitive forhold ved de jyske badesteder. Fra disse kunstnerkredse spredtes kendskabet til Skagen til andre sociale kredse og stedet befæstede sit ry som udflugtmål. Men Fanø, nej.

For Fanø kom det til at gå helt anderledes. Afsættet til øens kommercialisering, civilisering og inddragelse i borgerskabets Europa havde to afgørende forudsætninger. Der var for det første i løbet af 1880' erne et stort europæisk borgerligt publikum, der havde tid og råd til at tage på kurbadeophold. Det var mondænt at være på kurophold mindst én gang om året, og helst skulle man prøve nye steder og se nye mennesker. I flere europæiske lande med et købedygtigt overklassepublikum var det fysisk ganske umuligt at skaffe plads til de mange ved kysterne, hvis der overhovedet var kyst til rådighed. Derfor blev kursteder lagt ved kilder, søer, floder osv., men for et vist klientel var søkurbadet det eneste rigtige. Det gav rige muligheder for anlæggelse af store kurbade, hvor det mondæneliv gennemspilledes i sommerhalvåret. Kuren eller hensynet til helbredet var påskuddet for badelivet, og naturen egentligt kun en kulisse, som man forskansede sig imod med en række civilisatoriske indgreb.

\section{Et internationalt badested i Danmark}

I 1888 var der en meget omfattende Nordisk Udstilling i København, som kaldte mange udlændinge til, langt flere end arrangørerne havde regnet med. Gæsterne gav sig også tid til at se dele af Sjælland, rapporterede hjem 
om herlighederne og kaldte endnu flere til. Successen gav stødet til oprettelsen afDanmarks Turistforening, bag hvilken stod en kreds af højremænd, der ønskedeat sælge Danmark til Europa som turistmå1 ${ }^{6}$. En af deres første handlinger var at tage initiativet til at få startet et såkaldt "internationalt badested" i Danmark. Når der rundt omkring i Europa kunne bygges sådanne badesteder ved kysterne, måtte det også kunne lade sig gøre i Danmark. Ostendeved den belgiske kyst havdeværet et mondænt badested i snart et halvt århundrede; hvert år kom tusinder af turister og brugte en masse penge. En lignende guldgrube så turistforeningens ledere gerne i Danmark, og ikke blot beskedne efterligninger som på Sild, Føhr og Norderney. Men hvor?

Valget faldt på Fanø, og skal vi forklare hvorfor, er det ikke nok at henvise til interessenternes egen fremhævelse af Fanøs fordele: Den ualmindeligt brede forstrand, det udmærkedebølgeslag, vandets saltholdighed og temperatur, klitternes skønhed m.m. Eller at ingen af de vesterhavsøer, der hidtil havde tjent som badesteder, i så høj grad som Fanø besad alle de fortrin, som man kræver af et badested. Nej, Fanø havde to umiddelbare fordele ud over alle de øvrige fortrin: Der var ikke i forvejen etableret kommercielle turistinteresser på øen; det vil sige, der var ingen konkurrenter til at tvinge grundpriserne op, heller ikke på forstranden. Det var det væsentligste led ved beslutningen. Som noget ret enestående i Danmark ejer grundejerne på Fanø selv forstranden, modsat resten af landet, hvor det er staten. Øboerne havde købt Fanø af kongen i 1742 med alle de kongelige rettigheder. Dermed kunne et internationalt badested på Fanø udstrække sin ret helt til vandkanten, og i øvrigt stille særlige krav til alle besøgende på den private grund. For det andet var den geografiske beliggenhed god for et internationalt publikum fra såvel København, Skt. Petersborg som Hamburg eller London. Med skib eller tog til Esbjerg var det ligetil og for den sidste strækning fra Esbjerg til Fanøs vesterhavskyst var der kun tale om et mindre teknisk problem. Det skulle være til at løse, selv om det var mindre ideelt. Fordelene var flere.

Den 22. december 1889 blev der udsendt en "Indbydelse til aktietegning i Badeetablissementet 'A/S Fanø Nordsøbad"', underskrevet af såvel turistforeningens formand som flere bestyrelsesmedlemmer. Selskabet skulle råde over en aktiekapital på 200.000 kr., og forudsætningen for det hele var, at der blev opført et hotel med 50 værelser. Det var aftalen, at Fanø-folk skulle medvirke med $65.000 \mathrm{kr}$. og det øvrige land med 135.000 kr. Imidlertid gik det kun let med at skaffe pengene på Fanø. Der kom alle 
pengene ind til aftalt tid, vel takket være de mange redere og kaptajner på øen. Sejlskibenes og dermed Fanøs storhedstid som sejlerø med en meget stor handelflåde var endnu ikke forbi.

Derimod kunne man trods gentagne opfordringer gennem pressen ikke skaffe det nødvendige beløb fra det øvrige land. Der indkom kun 62.000 kr., hvilket end ikke var så meget, som Fanø selv bidrog med. Tilliden til Fanøs muligheder var åbenbart for begrænsede. Initiativet var dermed truet af forlis, og kun takket være lokal vedholdenhed kom det videre. Kaptajn $\mathrm{H}$. Rødgaard fra Fanø rejste til England for at prøve at skaffe den manglende kapital der, men uden held. Så gik turen til Hamborg, og her fandt ideen anderledes genklang. De tyske badesteder var ved den tid overfyldte, og med den dansk-tyske grænse ved Kongeåen, var der ikke langt for tyske turister til Fanø. Den tyske-østrigske bankier Sigmund Weisz tog mod tilbuddet og lagde straks foretagendet op i et endnu større format. Den grundlæggende aktiekapital blev udvidet fra de oprindelige 200.000 til 600.000 kr., hvoraf $25 \%$ straks blev indbetalt. Den første generalforsamling for A/S Fanø Nordsøbad blev afholdt i Hamburg i 1890. Det danske initiativ for et internationalt badested var endt som et helt igennem tysk domineret foretagende, hvor turistforeningens formand, lengreve Raben-Levetzau, ganske vist sad som formand støttet af kaptajn Rødgaard, men selskabet var under tysk kontrol. Dermed var Fanøs strand i realiteten kommet på tyske hænder, for aktieselskabet lejede stranden af grundejerforeningen for 100 år mod at betale $100 \mathrm{kr}$. i årlig leje, og samtidig blev det grundejerne forbudt at drive, hotel, pensionat, o.lign. i området op til stranden. Ja, grundejerne på Fanø måtte tilmed - ganske vist til minimale priser - betale for at benytte nordsøbadets badeindretninger. Dertil kom så, at selskabet fik tinglyst et særligt reglement for besøgende ved badet. Bl.a. kunne personer bortvises, hvis de optrådte anstødeligt eller på anden måde virkedegenerende. Reglementet gav også hjemmel til at afkræveen kurstakst af alle besøgende. A/S FanøNordsøbad varblevet et selvstændigt samfund på Fanø.

\section{A/S Fanø Nordsøbad regulerer badelivet}

Den daglige ledelse af aktieselskabet blev varetaget af kaptajn Rødgaard og tyskeren dr. Polacheck. De satte omgående store bygge- og vejarbejder $\mathrm{i}$ gang. Den smalle lyngvej fra Nordby til stranden blev udvidet og maka- 


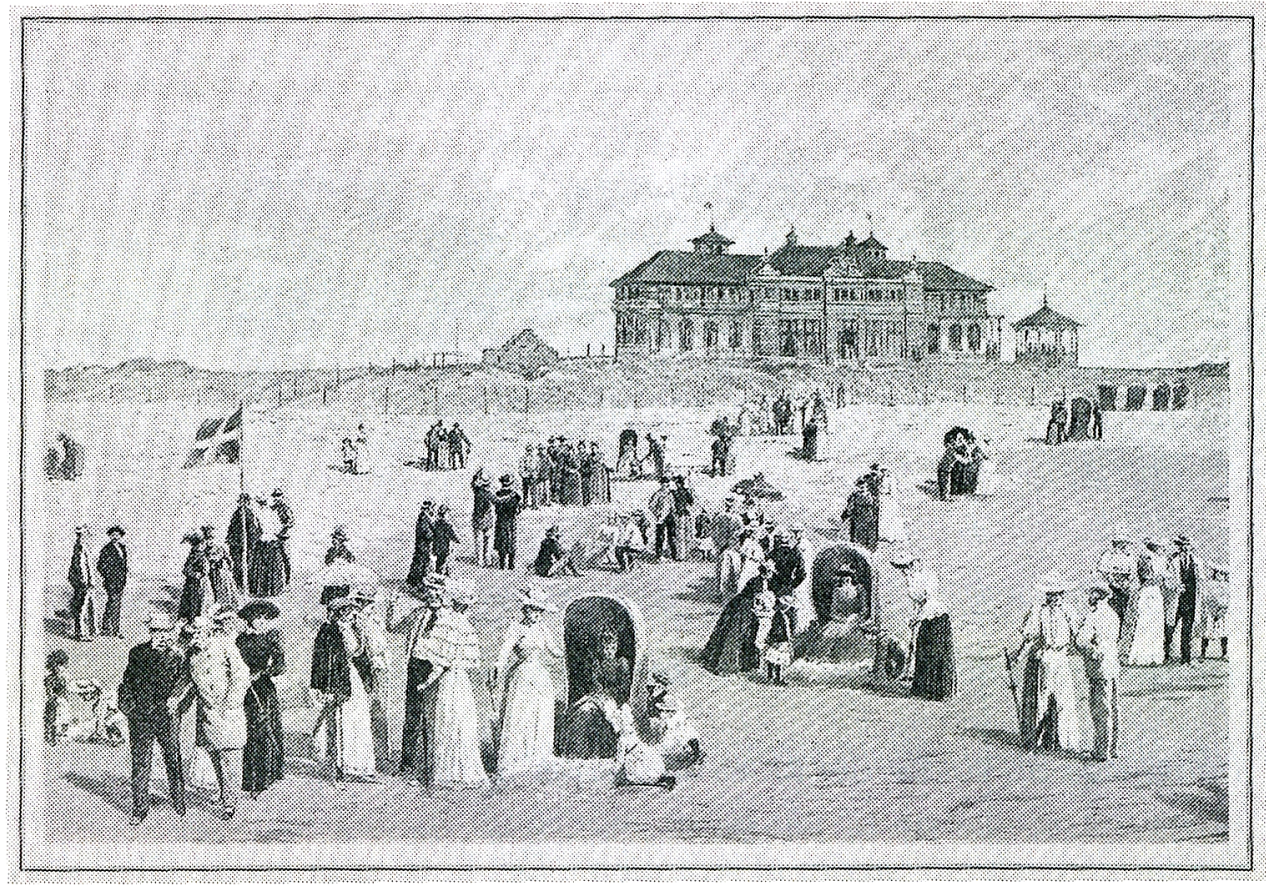

Stranden på Fanø foran det i 1892 åbnede Kurhotel. - Kort- og Billedafdelingen.

damiseret 1891-93 for $81.000 \mathrm{kr}$. Det var en uhyre stor sum. Mange gange mere end der årligt blev brugt på vejanlæg i Esbjerg ved samme tid, og timelønnen for en arbejder lå på 30 til 33 øre. I august 1891 blev grundstenen lagt til det første hotel, Kurhotellet, der blev indviet året efter, den 22. juni 1892. Det kostede i første omgang næsten $199.000 \mathrm{kr}$, hvortil kom inventar for $120.000 \mathrm{kr}$. Fra starten var det kun tænkt som kurhus, hvor badets festligheder og sammenkomster skulle afholdes, mens gæsterne skulle bo på de andre hoteller og i de planlagte, omkringliggende villaer. Det var derfor indrettet efter datidens internationale hotelstil med smukke kurlokaler, læseværelser og en kursal med plads til 400 mennesker. I sidste øjeblik blev der tilbygget 30 værelser med udsigt over havet.

Der kom gæster fra både København og Hamburg til indvielsen af hotellet. Fra Hamburg foregik det med et hurtigt ekstratog, der kun bestod af salonvogne. De rejsende fik frokost med champagne undervejs. Også københavnerne ankom i salonvogne, fire vogne i alt, med repræsentanter for handel, videnskab, kunst og presse.

Ved indvielsen talte formanden, lensgreve Raben-Levetzau, og han betonede stærkt, at Fanø Nordsøbad var dansk, selv om de fleste aktier var på tyske hænder! I øvrigt gjorde han opmærksom på, “at badningen 

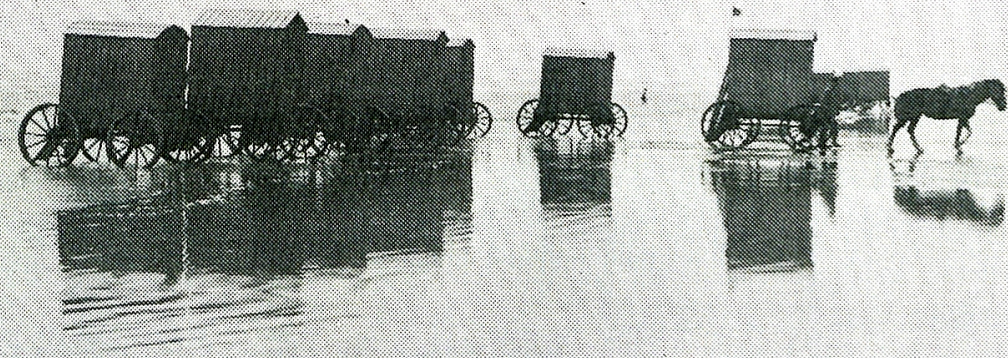

Hestetrukne badevogne på Fanø. - Kort- og Billedafdelingen.

finder sted fra vogne, der køres ud i havet, og damer og herrer kan, om de ønske det og anstændigt påklædte, bade sammen, men kan også bade hver for sig på bestemte steder af stranden". Det kom til at gælde alle badets gæster. Også dem der kom til på Strandhotellet, opført senere sammeår, og på Hotel "Kongen af Danmark", der blev taget i brug 1893. Tillige alle beboere i de luksusvillaer, der blev omført omkring hotellerne i de følgende år ${ }^{7}$. Kun Kurhotellet var i A/S Nordsøbadets eje; villaerne og de to andre hoteller var i uafhængige personers og interessentgruppers eje, men måtte indordne sig under aktieselskabets overordnede direktion. Heri lå også en konfliktmulighed, da det tyskdominerede aktieselskab med Kurhotellet stod overfor danske ejere på de to andre hoteller. Hotel "Kongen af Danmark" varsåledes ejet af en gruppe i Esbjerg omkring konsul Breinholst.

A/S Fanø Nordsøbad var et udpræget storborgerligt og stærkt civiliseret bad. Ikke noget med et umiddelbart møde med hav og natur efter en pludselig tilskyndelse. Alt var grundigt reguleret. Der var faste badetider: fra kl. 7-12 og 13-17.30, dog om søndagen fra 7-15. Der måtte kun bades, når badeflaget var oppe, og det var ikke af sikkerhedshensyn, men for at få badetiderne overholdt! Af- og påklædning skulle foregå i badevognene, der blev trukket ud i vandet af heste og tilbage igen, når de badende afgav signal derom fra vognen. Det kostede selvfølgelig penge for både børn og voksne, der i øvrigt kunne leje strandstole, strandtelte m.m. ved henvendelse til "strandmesteren" 8 .

Som badelivet var omhyggeligt reguleret, således blev omverdenen givet et entydigt billede af badestedets karakter. Det gælder lige fra A/ 


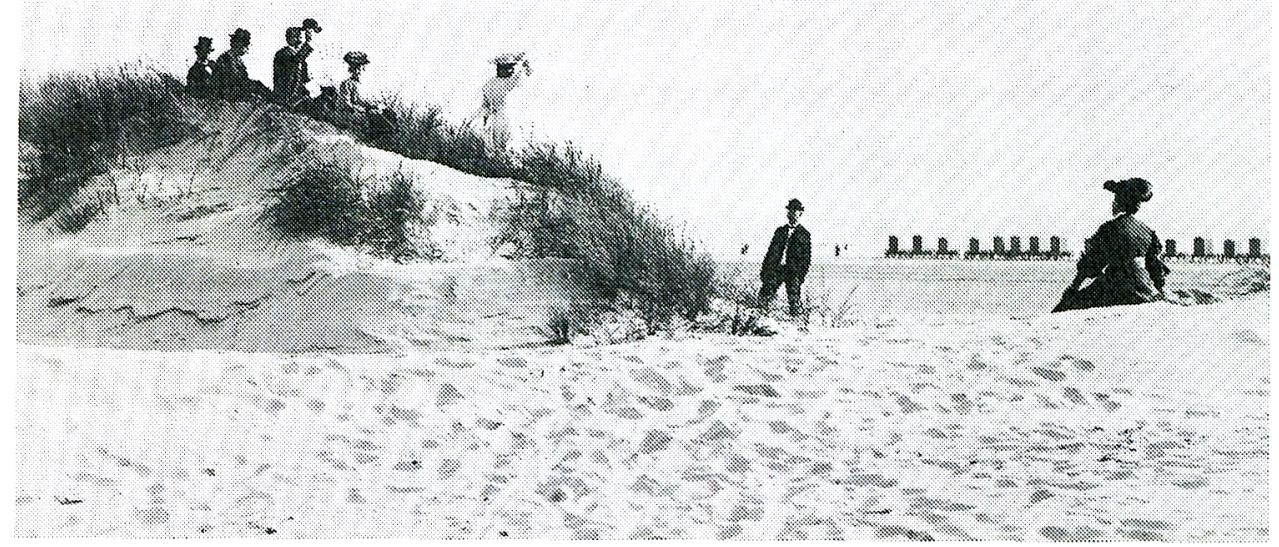

Strandgæster. Ved vandkanten ses badevognene. - Kort- og Billedafdelingen.

S Nordsøbadets reklametryksager til potentielle gæster i Europa, de samtidige avisreportager og turistguides: Det var udpræget eksklusivt. Efter en præsentation af Kurhotellet, Strandhotellet og Hotel "Kongen af Danmark" ien rejsefører fra 1897 tilføjes: "De her nævnte hoteller er store, monumentale, palælignende bygninger, omgivne af en mængde prægtigt udseende villaer, der lejes ud til badegæster; ... i øvrigt hverken træeller busk ... kun sand og atter sand ... Højst forunderligt virker derfor synet af disse hovedstadshuse, disse rigmandsvillaer i denne øde, golde natur". Senere fortælles om gæsterne: "Hovedmassen er danske og tyske, navnlig fra storbyerne København, Hamburg og Wien. Tilunderholdning for badegæsterne musiceres der hver eftermiddag af et orkester i Kurhotellets store sal, om formiddagen i musikpavillonen eller nede på strandbredden; af og til gæstes stedet af kunstnere som give koncerter, holde oplæsninger etc." 9

\section{Nordsøbadet og fannikerne}

Var Fanø nu rede til mødet med Europas borgerlige overklasse? Holger Drachmann gav udtryk for betænkeligheder på øboernes vegne. Han var med til indvielsen af Kurhotellet i juni 1892 som repræsentant for dansk kunst og kultur, fik forærende et lille grundstykke og var vidne til den ny livsstil, det europæiske storborgermiljø, der med ét blev plantet ved det yderste vesterhav. "Snart vil bourgeoisiet være derovre - herrer og fruer, frøkner og sønner. De vil spise og drikke, godt og meget - bringe priserne 


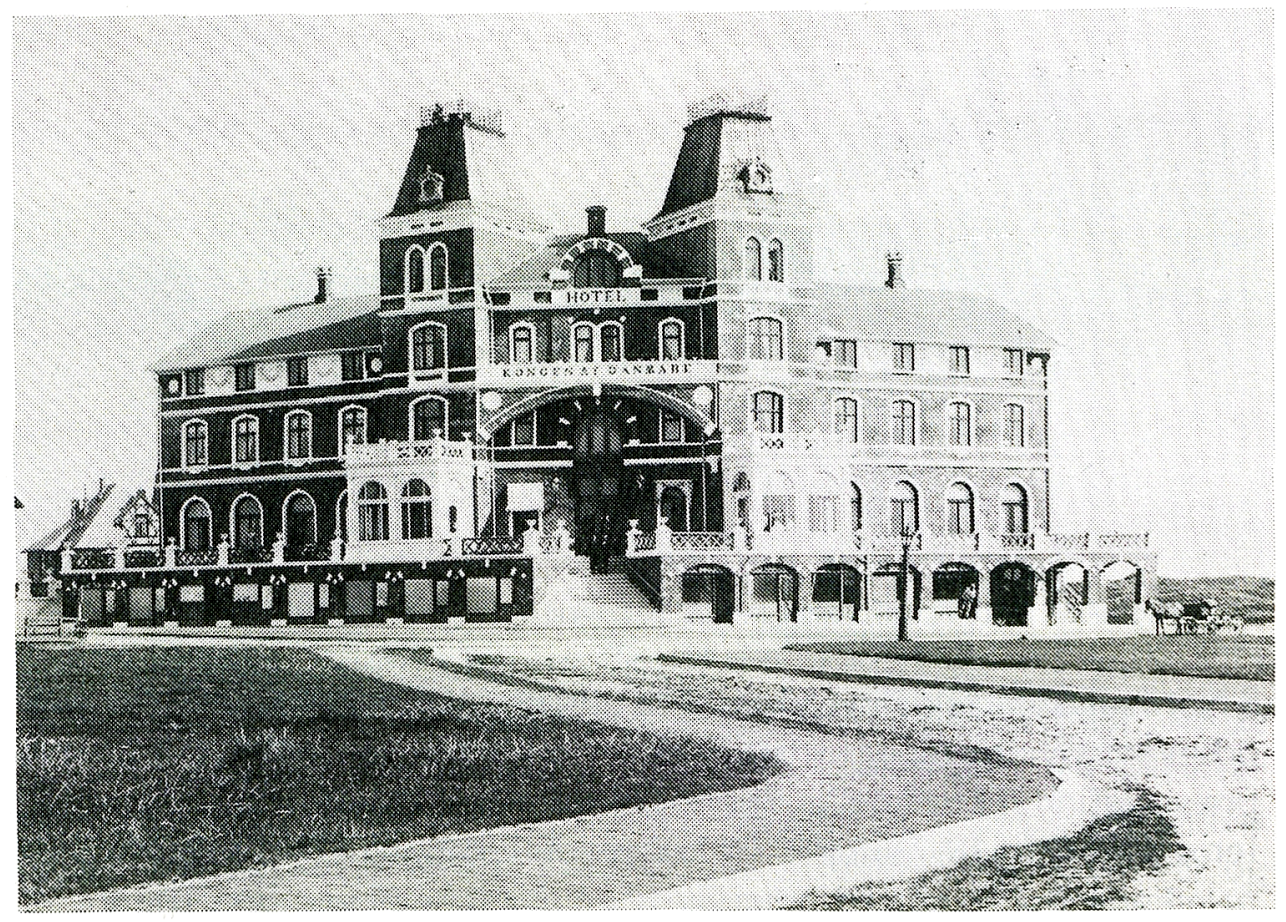

Hotel 'Kongen af Danmark', taget i brug 1893. - Kort- og Billedafdelingen.

i vejret på rariteter og køreture - de vil udvikle øboernes medførte sans for den store og lille tabel - vænne dem af med gæstfrihed - vænne dem til at finde nationaldragten komisk ... De vil mene at søge til naturen (dette begreb som de kender fra stambogsrim) for at vende styrkede tilbage til deres praksis, konsultationer, lediggang eller kontorslid. De vil kun opnå at slide naturen flad ved deres jagten omkring på cykel eller landauer ... Om en lille tid - hvis Vorherre holder sin hånd over badet - så vil Fanøboen været et moderne menneske, som smelter sammen med Europa. Han taler den internationale sportsjargon, bliver hotellier, medlem af det store broderskab med de høflige manchetter og de skarpe negle ... og så kommer turen til Manø. Det er udviklingen - det er tiden - det er skæbnen." 10

De lokale beboere var i nogleår tavse vidner til det, der foregik ved nordsøbadet uden for deres egne bymiljøer. På øen havde man selv villet det store badeprojekt, ellers havde øen ikke kunnet rejse den fornødne kapital i 1890. Det var imidlertid på et tidspunkt, hvor det endnu var et dansk projekt. Siden var det blevet tysk trods nok så mange forsikringer om det 


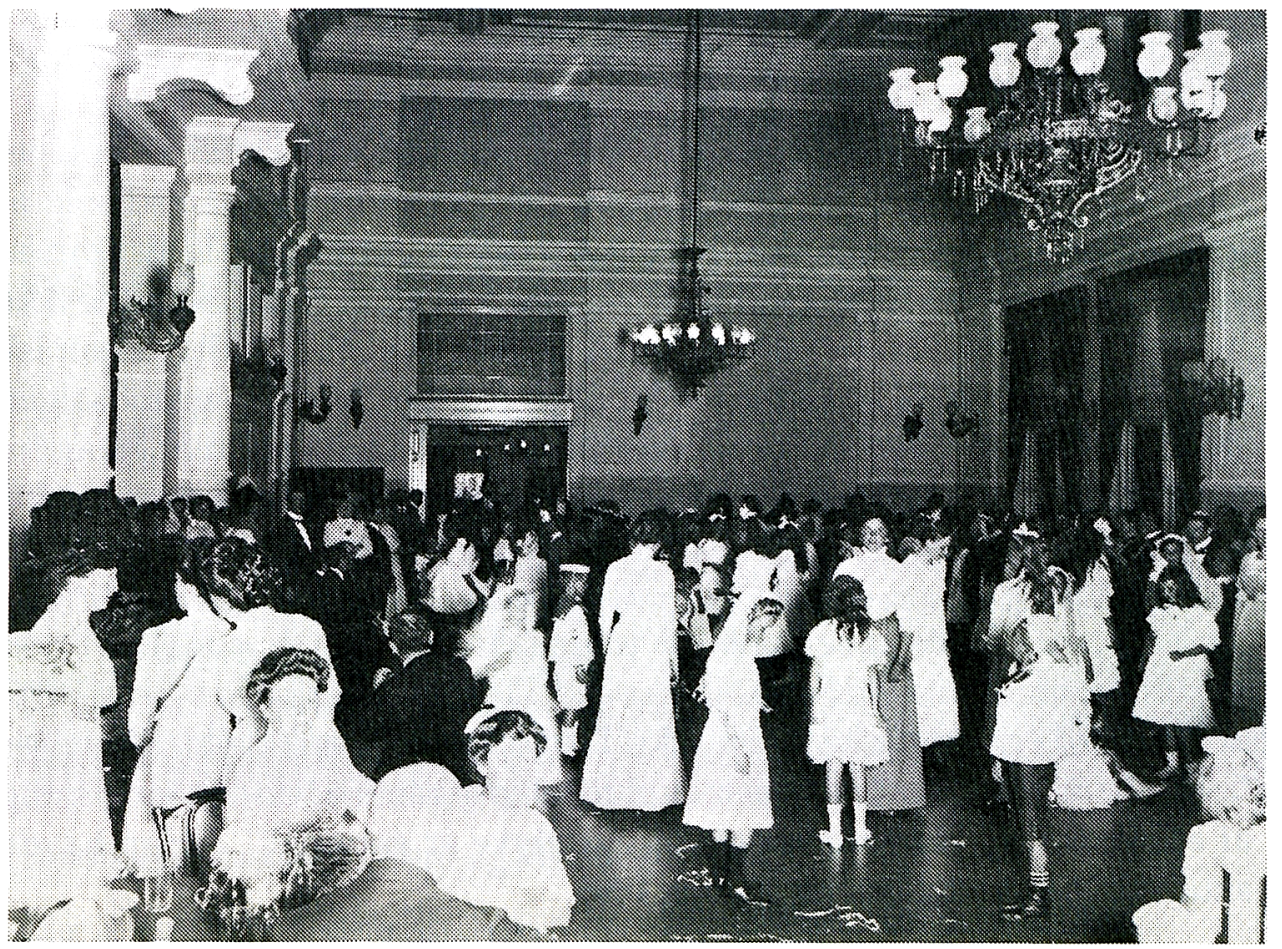

Interiør fra et badehotel. Et børnebal? - Kort- og Billedafdelingen.

modsatte. Når Hamburg-bankieren Sigmund Weisz ankom til Fanø med potentielle kunder til de meget dyre grunde omkring hotellerne, optrådte han som fyrste og ønskede at blive behandlet derefter. Fannikerne fik rollen som undersåtter. Nordsøbadets egne vogne var ikke gode nok til Weisz, så han fik transporteret en ekvipage over fra Esbjerg, så det kunne gå ordentligt til undervejs fra Nordby til badet. For at understrege det fyrstelige kastede han sølvpenge i grams til de forsamlede Fanødrenge ved færgens ankomst til Nordby. Weisz ønskede, at Nordbyfolkene flagede, når han ankom med sit selskab til øen, men det var at gå for vidt. Nok ville man gerne tjene på søbadet, men man ville ikke kommanderes og kostes med af folk udefra. Færgen var i øvrigt på det tidspunkt og frem til $1918 \mathrm{i}$ privat eje og var almindeligvis til befordring af jævne folk, hvorfor et opslag ned til den beskedne kahyt meldte: "Det forbydes passagererne at have smågrise på skødet i kahytten". Sådan var de sociale og kulturelle modsætninger, der mødtes på øen, hvor de højhælede damer ved badet var fra en anden verden for de lokale, og andre mindreåbenlyse modsætninger føjedesig til. 


\section{Pludseligt afgået ved døden ...}

Weisz investerede mange penge i Fanø Nordsøbad. I 1895 er beløbet beregnet til $750.000 \mathrm{kr}$., hvoraf dog en del var kommet ind ved salg af grunde, men alligevel skulle omkring $200.000 \mathrm{kr}$. forrentes. Hertil kom, at badets løbende driftsomkostninger var store, så store at indtægterne ikke holdt trit med udgifterne. Derfor kunne det hele kun løbe rundt økonomisk i kraft af, at der hele tiden blev solgt flere grunde. Svigtede grundsalget, blev Nordsøbadet en underskudsforretning. Weisz havde mange andre foretagender i gang og tabte penge på dem. Han besluttede sig derfor i 1895 til at få frigjort noget af sin investering i badet. Af de københavnske aviser fremgikdet, at et stort engelsk konsortium var interesseret. Der havde først været følere ude til københavnske interessenter, men danske investorer turde ikke binde an med Fanø Nordsøbad. Det viste sig hen på foråret 1896, at det gjorde de engelske heller ikke. Derpå kunne man i de lokale aviser læse: "Banquier Sigmund Weisz er pludseligt afgået ved døden formentlig af et hjærteslag. Han blev nogle og fyrretyve år gammel." - Han havde skudt sig på sit kontor den 30. maj 1896.

Da krudtrøgen havde lagt sig, stod eksekutorerne med et konkursbo, der skulle realiseres. Påny var der en mulighed for at få kurbadet på danske hænder, og atter strandede det på manglende interesse. Konkrete tilbud til en kreds af københavnske rigmænd stødte ikke på velvilje, og en enkelt af dem skulle få måneder senere støde badets vitale interesser i en sådan grad, at dets eksistens kom i fare. Det var brygger Carl Jacobsens weekend-besøg i august 1896, der vendte op og ned på alt eller rettere udløste de nationale spændinger, som lurede på Fanø og i det øvrige land i disse år.

Forud var gået følgende episode, der i sig selv var banal, men dog klart viser, hvilken stemning der herskede. Generaldirektør og chef for Norddeutsche Lloyd i Bremen, G. W. Lohman, ejede en af villaerne ved Nordsøbadet og var på feriedéri juli 1896. Han var tillige tysk marineofficer, ogda det danskeinspektionsskib “Beskytteren” vari Esbjerg havn, benyttede han lejligheden til en visit ombord, hvorefter han inviterede officererne til en genvisit og middag på Kurhotellet næste dag. For at hædre gæsterne, hævdede han senere, hejste han det tyske flag på sin villa. Andre af badets gæster fandt det imidlertid for provokerende og bad ud på dagen, om at flaget blev strøget. Det gjorde generaldirektøren så, omend han var irriteret. Dermed skulle den sag være ude af verden. Det var den 19. juli. 


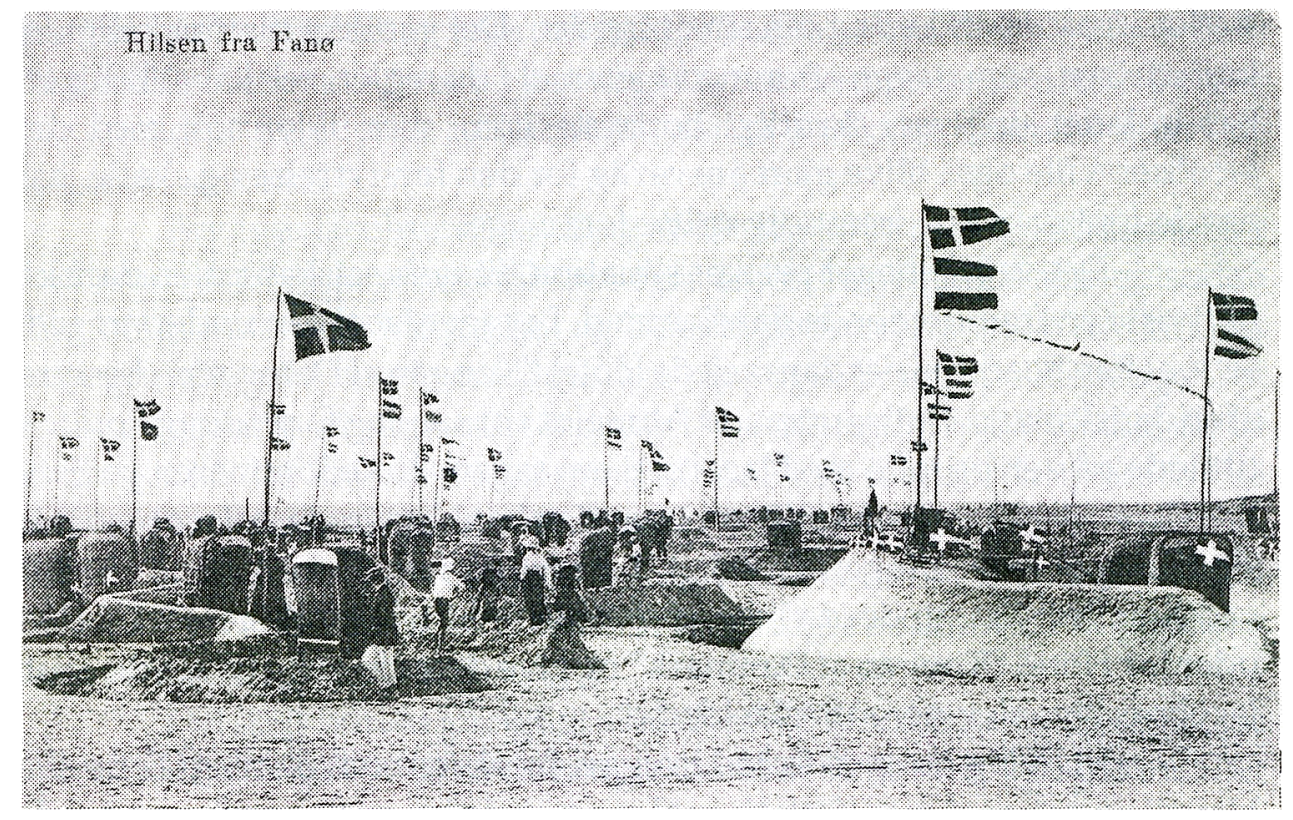

Sandborge. Postkort. - Kort- og Billedafdelingen.

\section{Brygger Jacobsen en weekend på Fanø}

Brygger Carl Jacobsen kom til Fanø den 4. august ud på eftermiddagen og tog ind på det danskejede Hotel "Kongen af Danmark", hvor hans hustru og børn var på ferieophold. Han fik af hotellet direktør, Poul Møller, efter middagen tilfældigt genfortalt historien om det tyske flag, der var blevet strøget godt 14 dage før. Senere spadserede Jacobsen på stranden med sin søn. Der var masser af sandborge og sandvolde lavet af børnene i løbet af dagen, og nogle var forsynet med en række af danske eller tyske flag. Jacobsen fortæller selv: "Deri var jo intet mærkeligt, da øen er dansk og badestedet tysk. Men et par steder var det danske flag på den øjensynligste måde hånet. Øverst på stangen vajede et større tysk flag og nedenunder på den samme stang var der fastgjort et ganske lille dansk flag"11. Så tog begivenhederne fart. Jacobsen slog flagstangen omkuld med sin stok, rev det tyske flag itu og kastede det $i$ vandet. Det gentog sig ved endnu en sandvold, før tyske gæster kom til og skældte ud. De truede bryggeren med prygl, så han fortrak til sit hotel. Imidlertid steg forbitrelsen blandt de tyske kurgæster, der gik til aktieselskabets direktion og klagede over ham. Direktionen krævede en undskyldning af Jacobsen, som nægtede og i 
stedet afgav en erklæring om sin optræden. Det var ikke tilstrækkeligt for kurledelsen, som dagen efter med hjemmel i de regler, selskabet tidligere havde ladet tinglyse, skriftligt bortviste ham, men ikke nok med det: Jacobsen ville også blive gjort ansvarlig for den forstyrrelse og skade, han havde forårsaget og fremtidig måtte forårsage.

Det var en noget prekær situation. Et tysk selskab på en dansk ø bortviste en fremtrædende dansk mand. Brygger Jacobsen understregede selv, at han boede på det danskejede Hotel "Kongen af Danmark", bestyret af en danskmand. Stiftsamtmand Ahnfeldt var søndag formiddag kommet til stede på øen og talte med Jacobsen om sagen. Birkedommeren på Fanø kom ligeledes til stede, og stiftsamtmanden konkluderede, at Jacobsen ikke skulle tage bortvisningen alvorligt. I stedet fik han en betjent på patrulje ved hotellet. Det hindrede ikke en tæt skare af tyske turister $i$ at samles udenfor Hotel "Kongen af Danmark" og give deres mishag til kende. Viste Jacobsen sig, blev der råbt skældsord.

Mandag morgen forlod brygger Jacobsen som planlagt Fanø. Det blev til en national manifestation. "I morges da jeg rejste var der en hel del mennesker samlede ved afgangsstedet for postbåden; de danske råbte hurra, tyskerne peb og skældte; jeg stod ude i agterstavnen og viftede med flaget til farvel". Forinden havde præsten i Nordby hyldet ham i Danmarks navn.

\section{Nationale modsætninger}

Dermed var en beklagelig episode overstået og ville efter al sandsynlighed hurtigt være blevet glemt, hvis ikke den lige netop havde rørt ved dybe nationale stemninger hos såvel tyskere som danskere. På dansk side var det besatte Sønderjylland ikke glemt, og ofte blev man i lokalsamfundet mindet derom ved de mange bånd, personlige såvel som merkantile, der var blevet skåret over af Kongeå-grænsen. På tysk side var den nationale stolthed tiltagende, og det må ikke glemmes, at det var en del af den tyske overklasse, der havde fundet sig til rette på Fanø. Den lod ikke en national provokation passere i et lokalt miljø, som den socialt og kulturelt følte sig hævet betydeligt over. Hvad bildte de lokale sig ind. Der var ikke den loyalitet, som kurgæsterne var vant til syd for grænsen. Ikke nok med at Jacobsen blev hyldet, men stiftsamtmandens og de øvrige lokale autoriteters støtte til ham var mere end de tyske kurgæster kunne bære. De begyndte at rejse hjem, og da avisreportagerne nåede frem, danske som tyske, blev 
grøften mellem dansk og tysk om muligt endnu større. Der blev hverken i de danske eller tyske aviser gjort noget for at dæmpe gemytterne. Følgen var at endnu flere tyske gæster rejste derfra for ikke at komme igen i de følgende sæsoner.

Brygger Jacobsens handling en lørdag på Fanø fik årelange følger for Fanø. For bryggeren selv fik den også en vis betydning. Fanø-episoden blev bragt frem for både Justits- og Udenrigsministeriet, men der fandtes intet grundlag for nogen anklage. Den blev også bragt op i Rigsdagen, til hvilken Jacobsen så sent som i februar 1904 måtte afgive beretning, da en af de skadelidte krævede erstatning af Jacobsen for tabt fortjeneste. Fra sønderjysk side fandt Jacobsen til gengæld stor sympati for sin handlemåde. I landsdelen, der var underlagt tysk besættelse og med forbud mod Dannebrog vandt han nye venner. Breve og digte strømmede til Jacobsen med en hjertelig tak ${ }^{12}$.

Det begyndte at gå rigtigt skidt for A/S Nordsøbadet. Tysk presse opfordrede direkte tysktalende kurgæster til at blive væk, og også antallet af danske gæster gik ned. De ønskede ikke at risikere at få en ferie spoleret. Grundsalget gik helt i stå, og dermed var rentabiliteten røget. Kurbadet skiftede tysk ejer flere gange, men selv om gæsterne gradvist kom igen, var nationalitetsdiskussionen tilbagevendende. Det skadede badets omdømme, og det blev ikke til det internationale badested, man havde drømt om fra starten. Kaptajn Rødgaard kom i klemme på den konto. Selv om han var en god dansker, undgik han ikke at blive lagt for had af sine bysbørn i sine sidste år. Han havde været med til at fremmane de store muligheder og havde skaffet de tyske forbindelser; pengene var også begyndt at strømme ind, men derefter gik det hele noget i stå. Han blev syndebuk for udviklingen. Han nåede tillige at komme i uniform, da bestyrelsen fik ny formand, en officer, André L. von Kapff, der indførte uniform for hele personalet og heller ikke lod Rødgaard slippe for uniform og kasket med mange stjerner.

En anden af hr. von Kapffs eller baron von Kapffs (det yndede han at kalde sig) initiativer var at få gang i sejlsporten omkring Fanø og især ud for badet. Han anskaffede en yacht og en stor sejlbåd, som om dagen i sæsonen skulle ligge fristende i vandet ud for badet. Han havde dog ikke taget tilstrækkeligt hensyn til naturforholdene. Igen og igen blev bådene presset på land ved de yderste revler for så med stor besvær at blive transporteret tilbage til Nordby med blokvogn. Derfra kunne de tage turen til badet ad søvejen næste dags morgen og måske ankomme til havnen 


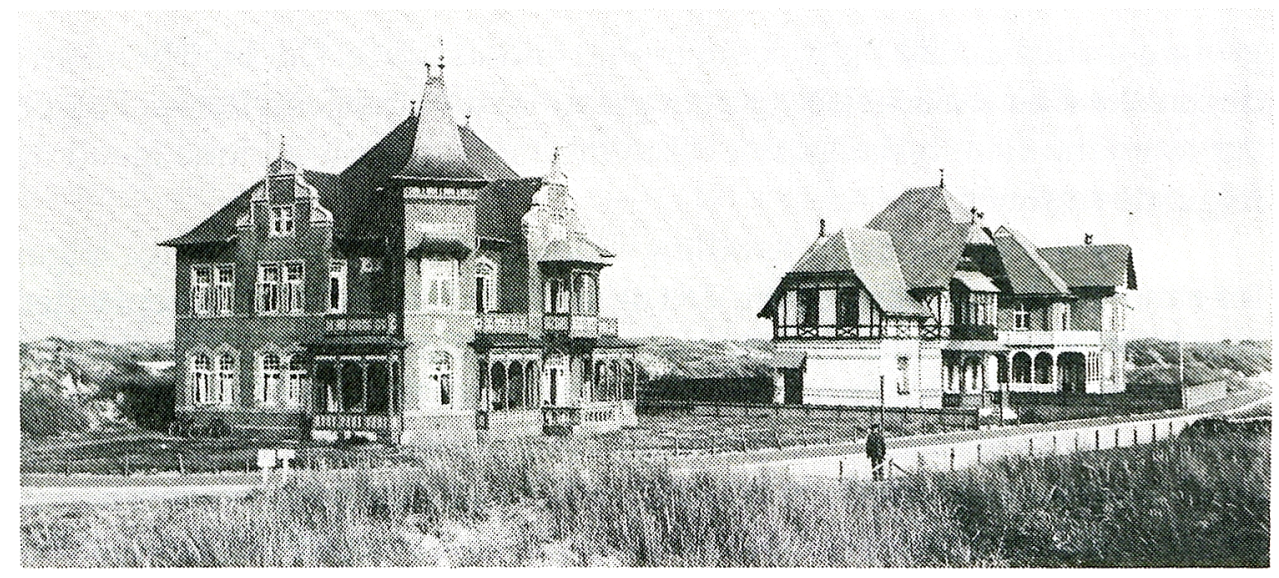

Ved siden af badehotellerne lå de store sommerhuse. - Kort- og Billedafdelingen

samme aften med blokvogn. Ikke underligt at de i folkemunde blev døbt "karrusellerne", og at "baronen" blev omtalt som "karruselejeren".

\section{Nordsøbadet skifter ejere}

Von Kapff solgte Nordsøbadet $\mathrm{i}$ august 1902 . Den nye tyske ejer beholdt dog kun badet til marts 1903 og nåede lige at lide et klækkeligt tab. Derimod var det en strålende forretning for Fanøs birkefuldmægtig J. N. Svarrer, som hver gang skrev skøderne. Omkostningerne ved ejerskiftet var 3.000 kr., så han bad til, at kurbadet ville forblive i bestandig cirkulation. Køberne i 1903 var to berlinere, P. Dähne, en blodrig pommersk junker, og Georg Thieme, en lille forsigtig, indskrumpet apoteker. Dette makkerpar skulle nu søge at vinde badestedet et godt omdømme. Rollefordelingen afslørede sig hurtigt med Dähne som den, der åbenlyst tog de store og kostbare beslutninger, mens Thieme kom listende bagefter og skar ned på kravene. Thieme havde det sidste afgørende ord, hvilket dog længe blev holdt skjult for omgivelserne.

Først og fremmest ville deny ejere forbedre transportmulighederne til og fra Fanø for de tyske kurgæster. Forholdene var således, at de tilrejsende sydfra med tog altid måtte vente to til tre timer i Lunderskov, før de kunne komme videre med toget til Esbjerg. Dähne fik den oplagte ide at oprette en direkte dampskibsforbindelse mellem Westerland påSild og Fanø. FraSild havdeHamburg-Amerika-Linien udmærkedeskibsforbindelser til det øvrige Tyskland. Dähne chartrede derfor et skib "Hebridean" på 330 


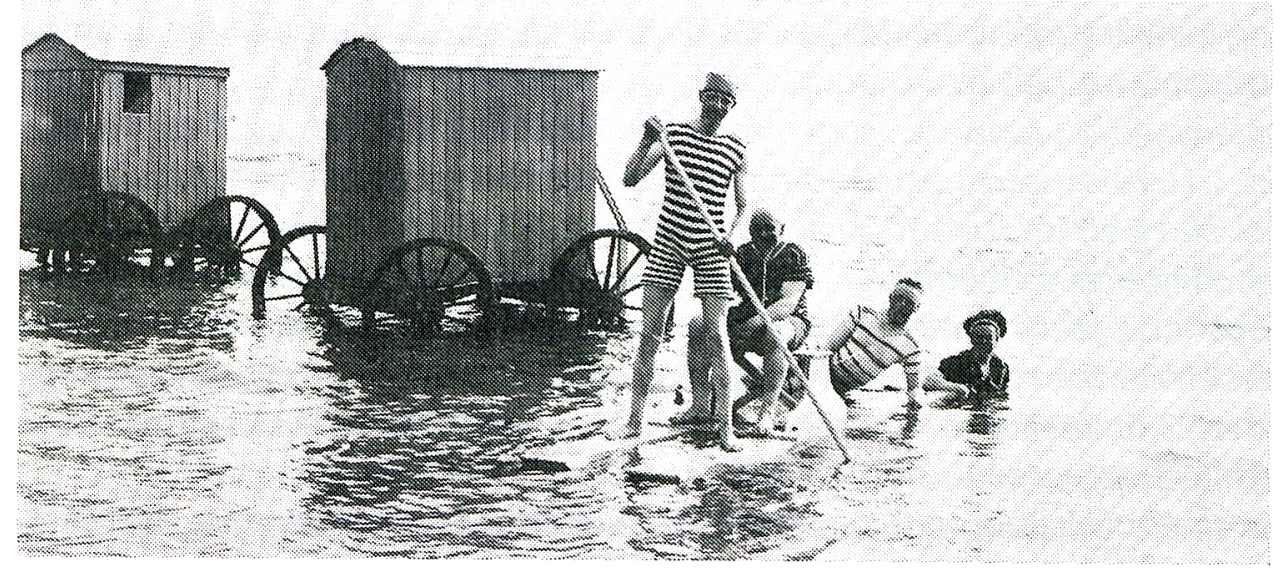

Badning fra badevogne omkring århundredskiftet. - Kort- og Billedafdelingen.

registertons med en sejlhastighed på $101 / 2$ knob. Kahytter var der kun få af, men da sejladsen skulle foregå om dagen, var det underordnet, da der ellers var plads til 100 passagerer. Dähne var selv meget tilfreds med sin disposition og beregnede billetindtægten for den første sæson på tre måneder med tre ugentlige afgange i hver retning til $80.000 \mathrm{kr}$., hvortil kom en restaurationsomsætning på $30.000 \mathrm{kr}$. Herimod var lejen af skibet på 30.000 mark plus alle omkostninger. Efter det regnestykke kunne det ikke gå galt.

"Hebridean" ankom til Esbjerg den 27. juni 1903. I den anledning var makkerparret personligt mødt op på havnen, passende påklædt med sømandskasketterne med de von Kapffske stjerner. Ind i havnen stævnede en gammel skotsk kreaturdamper, ubeskrivelig snavset og underligt højtliggende i vandet, som om man havde sparet på ballasten. Nok så megen rengøring kunne ikke gøre damperen mere egnet til transport af kurgæster, der var blot en smule forvænte. Fanøfærgen var luksus ved siden af. Ikke sært at Thieme blev mindre kry, mens Dähne smed kasketten. Videre måtte de imidlertid, og påny blev der udsendt indbydelser til repræsentanter for handel, presse, videnskab og kunst i København og Hamburg til indvielsesturen. Der ventede alle en enestående oplevelse.

Det viste sig, at damperen var ret dybtgående og derfor i det delvist fladbundede vesterhav måtte ret langt ud for at komme uden om sandbankerne. Især ved Sild gav det problemer, da der kun var et eneste sejlbart sted for "Hebridean", og det endda kun ved højvande. Det medførte, at damperen hver dag skulle være parat til at gå ind til Sild på et ganske bestemt tidspunkt, men dette tidspunkt skiftede fra dag til dag med højvandstiderne. Resultatet var, at afgangstiderne ikke kunne være faste, 
og i stedet måtte henlægges til de mest besynderlige tider for at følge tidevandet. Naturen bestemte fartplanen, hvilket var imod al civilisation, men med "Hebridean" som transportmiddel var der ikke noget at gøre ved det. Civilisationen fejrede heller ingen triumfer på indvielsesturen. Turen til Sild fra Nordby forløb nogenlunde; enkelte fik spist af det kolde bord. Anderledes på hjemturen. Vinden gav en prøve på sin kunnen. Det blæste op, damperens manøvrer tog længere tid og ingen var i stand til at indtage fast føde. Søsygen bredte sig blandt handel, kunst, presse og videnskab på den 23 timers tur til Fanø. Der var ikke feststemning, da gæsterne gik i land i Nordby.

Ialt fik ruten Fanø-Sild 43 betalende passagerer i den første og eneste sæson 1903. Udgifterne til ruten var omkring $80.000 \mathrm{kr}$. Det svarer til $1860 \mathrm{kr}$. pr. passager. En faglært arbejder havde ved den tid omkring 1.000 kr. i årsløn ${ }^{13}$. Man kunne have sendt passagererne frem og tilbage flere gange over Atlanten for den pris. Makkerskabet mellem Thieme og Dähnes var nær sin afslutning. De kunne ikke tåle at se hinanden, og det udartede til at blive et mål i sig selv for dem at krydse hinandens planer. Dog skulle de have kurbadet solgt. Det krævde et vist samvirke.

\section{Fra Nordsøbad til Vesterhavsbad}

Thieme rejste til København i efteråret $1903 \mathrm{i}$ håb om at få badet solgt. Køberne var imidlertid afventende. Som en af dem, direktør H. B. Linnemann, fastslog, burde indtjeningsmuligheder og købesum stå $\mathrm{i}$ et realistisk forhold til hinanden og skulle der sættes penge til, var det bedre, at tyskerne gjorde det end danskerne. Man ventede derfor.

Linnemann havde på endnu et punkt en helt korrekt fornemmelse, nemlig at Thieme for enhver pris ville komme makkeren Dähne på tværs. Det var lykkedes Dähneat sælge kurbadet i Hamburg for 200.000 kr., dog skulle Thieme give sin godkendelse. Thieme telegraferede derpå til Linnemann, som straks rejste til Berlin. Her tilbød han Thieme $125.000 \mathrm{kr}$. med det resultat, at denne var ved at få et apoplektisk tilfælde og gik sin vej. Imidlertid kom han igen, som Linnemann mindst havde ventet ham, og de afsluttede en handel. Linnemann lod sig presse til at give $137.000 \mathrm{kr}$. for kurbadet. Thieme skrev under på både Dähnes og egne vegne i kraft af sin fuldmagt til at få det sidste ord. Til afrunding af billedet af det tyske ejerskab af kurbadet hører, at Dähne og Thieme måtte igennem en retssag med hinanden over den indgåede handel. Dähne fik 25.000 kr. i erstatning. 
Kurbadet har siden været på danske hænder. Straks i 1904 blev navnet ændret til "Fanø Vesterhavsbad" for at slette det dårlige omdømme. De betingelser, som distriktslæge Lorcki 1865 havde fremholdt til fordel for Fanø, omgangen med en loyal befolkning, var nu helt og fuldt til stede. Det blev dog aldrig derefter helt det internationale badested, man havde sat næsen op efter omkring 1890. De sociale forventninger til gæsterne blev skruet noget ned, og nok var det internationalt, især med mange tyske gæster, men det var mest dansk. Også ejerskabet til de opførte luksusvillaer gik over på danske hænder.

Tyskerne har været gæster på Fanø siden, ikke ejere. De var mindre velkomne 1940-45, men snart gled de år i baggrunden. Turisme er mest forretning, selv om nationale stemninger, som eksemplet A/S Fanø Nordsøbad viser, kan komme grumme på tværs. I dag er en udbredt holdning vist den, som Esbjergs Turistchef, Ejgil Rasmussen, i 1950'erne gav udtryk for om de tyske gæster ved danske strande: "Personligt vil jeg hellere se 100 nøgne tyskere end een i uniform!"14 .

Noter

1 N. M. Kromann: Fanøs historie 3, 1934, s. $425 \mathrm{ff}$.

2 Folkekalender for Danmark 1855, s. 86.

3 Hospitalstidende, nr. 25, 1865.

- A. Falkman: Fra Danmarks Far-West, 1879, s. 81, 86f.

5 Nutiden, nr. 238, 1881.

- Xenius Rostock: Turisme i Danmark, Turistforeningen for Danmark. Årbog 1938, s. 7-148, her s. 75-80.

7 Olaf Lassen: Badestedet Fanø igennem 50 \& r. 1890-1940, 1950, s. 26-38. Hvor intet andet anføres i det følgende, er dette skrift af selskabets direktør igennem mange år, kilden.

- Fanø og omegn. Illustrerede rejsebøger, nr. 18, 1897, s. 13f.

- Fanø og omegn. Illustrerede rejsebøger, nr. 18, 1897, s. 14-15. Jfr. Oscar Bruun: Esbjerg og Fanø, Dansk turistforenings årsskrift 1898, s. 116-128, her s. 127-28. Bruun taler nødvendigvis pænt om dette "badested af rang", men lader skinne igennem, at han personligt mener noget andet.

10 Holger Drachmann: Fanø, o Fanø -, Tilskueren 1894, s. 505-521, her s. 519- 21.

1 Politiken 5. august 1896 for dette og det følgende.

12 Johs. Steenstrup: Carl Jacobsens liv og gerning, 1922, s. $236 f$.

13 Svend Aage Andersen: Salt og brød gør kinden rød, 1985, s. 131.

14 Ejgil Rasmussens erindringer, 1990, s. 50. 